'Anonymous. Dissolving hopes for gallstone dissolution? Lancet 1981 ;ii 905-6.

${ }^{8}$ Small DM. The staging of cholesterol gallstones with respect to nucleation and growth. In: Paumgartner G, Stiehl A, Gerok W, eds. Bile acids and lipids. Baltimore: MTP Press, $1981: 291-300$.

${ }^{9}$ Bell GD. The present position concerning gallstone dissolution. Gut $1974 ; 15: 913-29$.

10 Ruppin DC, Dowling RH. Is recurrence inevitable on withdrawing treatment after complete dissolution by bile-acid treatment? Lancet $1982 ; \mathrm{i}: 181-5$

11 Anderson JC, Harned RJ. Gray-scale ultrasonography of the gallbladder an evaluation of accuracy and report of additional ultrasound signs. Am f Roentgenol 1977;129:975-7.

12 Simeone JF, Ferrucci JT. New trends in gallbladder imagery. $\mathcal{F} A M A$ $1981 ; \mathbf{2 4 6}: 380-3$.

${ }^{13}$ Cooperberg PR, Pons MS, Wong P, Stoller JL, Burhenne JH. Real-time high resolution ultrasound in the detection of biliary calculi. Radiology $1976 ; 131: 789-90$.
${ }^{14}$ Bell GD, Doran J. Gallstone dissolution in man using an essential oil preparation. Br Med f 1979 ; : 24

15 Ellis WR, Bell GD, Middleton B, White DA. Adjunct to bile acid treatment for gallstone dissolution: low dose chenodeoxycholic acid combined with a terpene preparation. $\mathrm{Br} M e d \mathcal{F} 1981 ; 282: 611$.

${ }^{16}$ Shapero TF, Lee V, Wilson RS, Rosen IE, Fisher MM. A problem in the evaluation of gallstone dissolution. Gastroenterology 1981;80:1348. (Abstract.)

${ }^{17}$ Bartrum RJ, Crow HC, Foote RT. Ultrasonic and radiographic cholecystography. $N$ Engl f Med $1977 ; 296$ :538-41.

${ }^{18}$ Bateson MC, Trash DB, Bouchier IAD. Can a six-month cholecystogram predict eventual response to gallstone dissolution therapy? Gut 1980; $21: 443$.

19 Bateson MC, Bouchier IAD, Trash DB, Maudgal DP, Northfield TC. Calcification of radiolucent gallstones during treatment with ursodeoxycholic acid. Br Med f $1981 ; 283$ :645-6.

(Accepted 22 March 1982)

\title{
Sarcoidosis and membranous glomerulonephritis: a significant association
}

\author{
R G TAYLOR，C FISHER， B I HOFFBRAND
}

\begin{abstract}
Three patients were seen who had sarcoidosis associated with glomerulonephritis. Subsequent review of published reports of cases in which the two conditions occurred simultaneously showed a pattern of histological type of glomerulonephritis different from that seen in patients without associated disease. In sarcoidosis with glomerulonephritis there appeared to be a dearth of minimalchange disease and an excess of membranous glomerulonephritis compared with the prevalence that would be expected if the renal disease was merely a chance occurrence.
\end{abstract}

These findings may provide evidence for an important relation between sarcoidosis and glomerulonephritis.

\section{Introduction}

Several mainly isolated cases have been reported of sarcoidosis and glomerulonephritis occurring in the same patient. Some workers consider this relation to be significant, particularly with respect to membranous glomerulonephritis, ${ }^{1}$ but others regard it as a chance occurrence. ${ }^{2}$ We recently saw three patients with histologically proved sarcoidosis and glomerulonephritis. The possibility of an association between the two diseases prompted us to review reports of similar cases.

\section{Case reports}

Case 1-A 24-year-old man presented in November 1973 with the nephrotic syndrome and normal creatinine clearance. Percutaneous

Department of Medicine, Whittington Hospital, London N19

R G TAYLOR, BSC, MRCP, medical registrar (now research fellow, respiratory unit, Hammersmith Hospital, London W 12)

B I HOFFBRAND, DM, FRCP, consultant physician

Department of Morbid Anatomy, Faculty of Clinical Science, University College, London WC1

C FISHER, MRCPATH, senior lecturer (now consultant histopathologist, Royal Marsden Hospital, London SW3) renal biopsy disclosed membranoproliferative glomerulonephritis with reduplication of the glomerular capillary basement membrane. Hypocomplementaemia was noted on several occasions. A chest $x$-ray film was normal in March 1979, but three months later he developed wheezing and was found to have bilateral hilar lymphadenopathy. A Kveim test yielded positive results. Serum calcium concentration and activity of angiotensin-converting enzyme were normal. Tests for circulating immune complexes by $\mathrm{Clq}$ binding were negative. His renal function and serum albumin concentration remained normal, though he continued to have heavy proteinuria and developed hypertension requiring treatment. The bilateral hilar lymphadenopathy persisted.

Case 2-In 1977 a 32-year-old man with longstanding epilepsy was found to have persistent haematuria and proteinuria, with granular casts in the urine and normal renal function. Histological appearances of a renal biopsy specimen obtained in January 1978 were those of segmental proliferative nephritis. In February 1980 he developed acute arthritis of both knees and ankles, erythema nodosum, and increased haematuria and proteinuria. Percutaneous renal biopsy confirmed the previous findings and indicated mesangial IgA disease. A Kveim test gave a positive result. A chest $x$-ray film was normal, as were the serum calcium concentration and angiotensin-converting enzyme activity. Circulating immune complexes as estimated by the polyethylene glycol precipitation method amounted to $152 \mathrm{mg} / \mathrm{l} \mathrm{IgG}$ (upper limit of normal $100 \mathrm{mg} / \mathrm{lgG}$ ).

Case 3-In June 1980 a 36-year-old man received penicillin as treatment for a tooth abscess. Proteinuria and haematuria were found a week later, and after a further two weeks he developed erythema nodosum. Creatinine clearance and serum calcium concentration and angiotensin-converting enzyme activity were normal. Percutaneous renal biopsy disclosed membranous glomerulonephritis. The overall appearances and the predominantly intramembranous distribution of the immune complexes were not entirely characteristic of an idiopathic membranous nephropathy but were not those of poststreptococcal glomerulonephritis. Serum complement concentration and the concentration of circulating immune complexes (polyethylene glycol precipitation method) were both normal. A chest $x$-ray film showed bilateral hilar lymph-node enlargement. Histology of a paratracheal lymphnode biopsy specimen showed typical sarcoid granulomas, and a Kveim test gave a positive result. His renal function remained normal, though proteinuria persisted.

\section{Review of literature}

We found 30 reports of cases of sarcoidosis and glomerulonephritis occurring in the same patient and examined critically the renal histo- 
logical evidence provided by the authors. We believe that one case, which was not categorised, was one of membranous glomerulonephritis and that another case, ${ }^{4}$ described as being of membranous glomerulonephritis, was one of proliferative glomerulonephritis. Two other cases, ${ }^{56}$ described as cases of proliferative and mesangioproliferative glomerulonephritis respectively, were, we believe, probably membranoproliferative glomerulonephritis. Table I compares the distribution of renal histological diagnoses in the 33 cases of glomerulonephritis associated with sarcoidosis with the distributions in two apparently non-selected series from Guy's Hospital ${ }^{7}$ and Newcastle. ${ }^{8}$ Membranous disease was significantly more common in the patients with sarcoidosis than in those in the Guy's series and considerably more common but not significantly so in the patients with sarcoidosis compared with the Newcastle series. We were unable to find a single case of minimalchange disease in the patients with sarcoidosis, the prevalence of such disease in the control groups being significantly higher.

TABLE I-Histology of glomerulonephritis in sarcoidosis and in primary glomerular disease. (Figures are numbers $(\%)$ of patients)

\begin{tabular}{lccc}
\hline & $\begin{array}{c}\text { Sarcoidosis } \\
(\mathrm{n}=33)\end{array}$ & $\begin{array}{c}\text { Guy's } \\
\text { series } \\
(\mathrm{n}=433)\end{array}$ & $\begin{array}{c}\text { Newcastle } \\
\text { series }^{*}\end{array}$ \\
\hline $\left.\mathrm{n}^{*}=143\right)$
\end{tabular}

Comparison of control groups with group with sarcoidosis: ${ }^{*} \mathrm{p}-0.01$ (Fisher's exact probability, test); ${ }^{* *} \mathrm{p}<0.05$ ( $\chi^{2}$ test with Yates's correction); ${ }^{* * *} \mathrm{p}-0.10$ ( $\chi^{2}$ tes tE R Randall, unpublished observations.

Table II compares the distribution of histological diagnoses in those patients with sarcoidosis who had the nephrotic syndrome with that in a survey of the nephrotic syndrome in adults from Guy's Hospital. ${ }^{24}$ Membranous glomerulonephritis was responsible for $60 \%$ of the cases of the nephrotic syndrome in sarcoidosis compared with $12 \%$ in the adults with primary glomerular disease.

TABLE II-Histology in the nephrotic syndrome in sarcoidosis and in primary glomerular disease. (Figures are numbers $(\%)$ of patients)

\begin{tabular}{lcr}
\hline & $\begin{array}{c}\text { Sarcoidosis } \\
(\mathrm{n}=15)\end{array}$ & $\begin{array}{c}\text { Guy's } \\
\text { series }^{24} \\
(\mathrm{n}=213)\end{array}$ \\
\hline $\begin{array}{l}\text { Minimal-change } \\
\text { Prombranous }\end{array}$ & $9(60)^{*}$ & $\begin{array}{r}70(33) \\
25(12)\end{array}$ \\
\hline
\end{tabular}

${ }^{*} \mathrm{p}<0.001\left(\chi^{2}\right.$ test with Yates's correction)

The temporal relations between the two diseases differed greatly. In 10 cases sarcoidosis was diagnosed up to 18 years before glomerulonephritis, and in four cases the renal disease presented up to 10 years before the sarcoidosis. Of the 28 patients whose sex was given, 19 were men. The mean age of these men at the time of diagnosis of the sarcoidosis was 28 (SD 7.9) years, compared with 41.3 (SD 12.6) years in the women $(p<0.01)$. In several cases, as in two of our patients, haematuria and proteinuria increased temporarily in association with erythema nodosum. The clinical range of sarcoidosis described with glomerulonephritis did not, however, appear in any way to be exceptional.

\section{Discussion}

Published reports and the experience of individual observers (D G James, unpublished observations) do not give any indication of a higher prevalence of glomerulonephritis in patients with sarcoidosis compared with the general population. Comparisons such as we made in this study are fraught with many sources of error. We believe, nevertheless, that there is a higher than expected prevalence of membranous glomerulonephritis in patients with sarcoidosis, with perhaps a reduced prevalence of minimal-change disease. Minimal-change disease is responsible for only about $5-10 \%$ of cases of adult primary glomerular disease. Although no case of minimal-change disease has to our knowledge been reported in sarcoidosis, at most no more than three in 33 cases of primary glomerular disease could be expected. The figures for membranous glomerulonephritis are, however, striking, and confirm the views of several workers who include sarcoidosis as one of the "causes" of membranous glomerulonephritis.

The altered immunological background of sarcoidosis ${ }^{25}$ may be relevant in modifying the histological expression of another group of immunologically determined diseases, glomerulonephritis.

We thank Dr S L Cohen for permission to report details of the patient in case 3 .

\section{References}

1 Kincaid-Smith P. The kidney-a clinicopathological study. Oxford: Blackwell, 1975:343-4

${ }^{2}$ Fish AJ, Michael AF. Immunopathogenesis of renal disease. In: Earley LE, Gottschalk CW, eds. Strauss and Welt's diseases of the kidney. 3rd ed. Boston: Little, Brown and Co, 1979:541-83.

${ }^{3}$ Etienne-Martin P, Klepping C, Guerrin J, Barthes H, Binet J, Duserre I. Syndrome néphrotique au cours d'une maladie de Besnier-BoeckSchaumann à localisation pulmonaire, osseuse et hépatique. Fournal de Médecine de Lyon 1962;43:193-8.

4 Taylor TK, Senekjian HO, Knight TF, Gyorkey F, Weinman EJ Membranous nephropathy with epithelial crescents in a patient with pulmonary sarcoidosis. Arch Intern Med 1979;139:1183-5.

${ }^{5}$ Briner J, Gartmann J. Glomerulonephritis bei Sarkoidose. Schweiz Med Wochenschr 1978;108:401-6.

6 Waldek S, Agius-Ferrante AM, Lawler W. Renal failure due to glomerulonephritis in sarcoidosis. $\mathrm{Br}$ Med 7 1978;i:1110-1.

${ }^{7}$ Cameron JS. The natural history of glomerulonephritis. In: KincaidSmith P, d'Apice AJF, Atkins RC, eds. Progress in glomerulonephritis. Chichester: John Wiley, 1979:1-26.

${ }^{8}$ Rashid H, Morley AR, Ward MK, Kerr DNS, Codd AA. Hepatiti Bs infection in glomerulonephritis. Br Med $\mathcal{f} 1981 ; \mathbf{2 8 3}: 948-9$.

${ }^{9}$ Berkman JI, Bernstein SH. Membranous glomerulonephropathy in association with sarcoidosis. In: Abstracts and free communications of the $3 r d$ international congress of nephrology, Washington, DC. Basel : $S$ Karger, $1966: 156$

${ }^{10}$ Falls WF, Stacy WK, Prazich JA, Abukurah AR, Stills WJS, Randall RE Non-hypercalcaemic nephropathy with sarcoidosis. In: Proceedings of the 4th annual meeting of the American Society of Nephrology. Washington, DC: American Society of Nephrology, 1970:24.

11 Laroche C, Merillon H, Morel-Maroger L, Turpin G, Uro J, Parrain E. Syndrome néphrotique avec glomérulite extra-membraneuse associé à une sarcoidose. F Urol Nephrol (Paris) 1968;74:995-1001.

${ }^{12}$ Mariani AF, Clifton S, Davies DJ, et al. Membranous glomerulonephritis associated with sarcoidosis. Aust NZ F Med 1978;8:420-5.

13 McCoy RC, Tisher CC. Glomerulonephritis associated with sarcoidosis. Am F Pathol $1972 ; 68: 339-58$

${ }^{14}$ Salomon MI, Poon TP, Hsu KC, King EJ, Tchertkoff V. Membranous glomerulonephropathy in a patient with sarcoidosis. Arch Pathol 1975; 99:479-83.

${ }^{15}$ Chun PKC, Hull S, Ball JH, Butkus DE. Sarcoidosis associated with glomerulonephritis: case report. Milit Med 1980;145:121-2.

${ }^{16}$ Correa P. Sarcoidosis associated with glomerulonephritis. Arch Patho $1954 ; 57: 523-9$.

17 Palestro G, Mazzucco G, Coda R. Glomerulonefrite e sarcoidosi : studio di un caso. Minerva Med 1975;66:4311-5.

8 Plattner HC, Nouskipel P, Morard JC. Néphropathie survenue au cours d'une sarcoidose de Besnier-Boeck-Schaumann: epilogue. $\mathcal{F}$ Urol (Paris) 1959 ;65 :213-6.

19 Brodwall EK, Øyri A, Øystese B. Intermittent benign renal haematuria Acta Med Scand 1971;190:545-8.

${ }^{20}$ Fauchald P, Brodwall EK, Myhre E. Fokal glomerulonefritt-et begrep som bør forlates. Tidsskr Nor Laegeforen 1972;92:494-6.

21 Lee SM, Michael AF. Focal glomerular sclerosis and sarcoidosis. Arch Pathol Lab Med 1978;102:572-5.

22 Wunsch R. Clinical pathological conference. Mich Med 1968;67:1455-9.

${ }^{3}$ MacSearraigh ET, Doyle CT, Twomey M, O'Sullivan DJ. Sarcoidosis with renal involvement. Postgrad Med $\mathcal{f} 1978$;54:528-32.

24 Cameron JS. Symptomless proteinuria and the nephrotic syndrome. Medicine 1977;28,2nd series:1527-38.

${ }^{25}$ James DG, Neville E, Walker A. Immunology of sarcoidosis. Am $\mathfrak{F}$ Med 1975;59:388-94.

(Accepted 18 March 1982) 